\title{
The Role of Science in The Management of Biodiversity: a Case of Stingrays (Dasyatidae) Research to Provide Basic Data for Aquatic Fauna Conservation in South Sumatra
}

\author{
Muhammad Iqbal ${ }^{1}$, Indra Yustian $^{2}$, and Hilda Zulkifli $^{2}$ \\ Conservation Biology Program, Faculty of Science, Universitas Sriwijaya, Jalan Padang Selasa 524, \\ Palembang, Sumatera Selatan 30139, Indonesia. \\ 2 Department of Biology, Faculty of Science, Universitas Sriwijaya, Jalan Raya Palembang- \\ Prabumulih km 32, Indralaya, Sumatera Selatan 30662, Indonesia. Email: hilda.zulkifli@yahoo.com
}

\begin{abstract}
The study of fish diversity had been reported accross the South Sumatran waters, but the study focus on stingrays (family Dasyatidae) were very limited. In general, many stingrays species face high level of direct exploitation. A recent study to provide valid checklist of stingrays in South Sumatran waters found 14 species: Brevitrygon heterura, Fluvitrygon kittipongi, Fluvitrygon oxyrhyncha, Fluvitrygon signifier, Fluvitrygon sp 'musi' 1, Fluvitrygon sp 'musi' 2, Himantura undulata, Himantura uarnak, Maculabatis gerrardi, Pateobatis fai, Pateobatis uarnacoides, Pastinachus ater, Telatrygon biasa and Urogymnus polylepis. Following IUCN (The International Union for Conservation of Nature) Red List status 2018, ten species of stingrays are threatened, with four species as Endangered, five species as Vulnerable and one species as Data Deficient. These findings suggest the South Sumatran waters are important habitat for stingrays in Indonesia, and immediate conservation actions plan is needed. In this paper, we demonstrate the role of science in biodiversity management with stingrays (Dasyatidae, an iconic group of rare and threatened fishes) as study case. 1 .
\end{abstract}

\section{Introduction}

Few species of stingrays are occur in Southeast Asia, particuarly in Indonesian waters $[1,2,3]$. In Indonesia, there are at least 40 valid species of stingrays where wide spread within main seven faunal regions. South Sumatra province is the largest province in Sumatra where located in the southeastern portion of the island. The study of fish diversity had been reported accross the South Sumatran waters [4], but the study focus on stingrays were very limited [5-7]. Study on stingrays diversity had been done in in South Sumatran waters, revealed relatively rich number of stingrays diversty[8]. Further review on biodiverstiy management is required to ensure population survive in the wild. This paper 
provide review the role of science to provide basic data for aquatic fauna conservation in south Sumatra

\section{Materials and Methods}

Records of stingrays in South Sumatran waters were obtained from local social media (mainly Facebook group of local anglers in South Sumatra province) and internet supported with photographs or other evidence (e. g. location, habitat type, morphology and description from anglers) during January 2016 to June 2018; provide an extension to the known distribution of this species and from unpublished data collected by first author. All specimens recorded were mainly from Musi River drainage (the largest and major drainage in South Sumatra) and east coast of Banyuasin. All records included herein were verified; and unconfirmed or ambiguous records were rejected. In addition, three field surveys were conducted in April 2018.

Systematically reviewed what potential solutions are needed to identify and what consensus and direction it provides to support management biodiversity to ensure population of the stingrays survive in the wild. For this reason, we adopt and modify conservation actions plan of stingrays proposed by [9] as reccomendation for management of biodiversity of rare and protected aquatic fauna in South Sumatran waters.

\section{Results and Discussions}

\subsection{Stingrays Diversity in South Sumatran Waters}

This study found 14 species of stingrays iin South Sumatran waters. The species checklist and localities are presented in Table 1. Taxonomy and scientific name follow recent update revision of family Dasyatidae by [2].

Table 1. Annotated checklist, status and habitat of stingrays found in South Sumatran waters, Indonesia

\begin{tabular}{|c|c|c|c|c|}
\hline No & Species & IUCN Status & $\begin{array}{c}\text { Protected by } \\
\text { Indonesian } \\
\text { law }\end{array}$ & Habitat \\
\hline 1 & Brevitrygon heterura & Data Deficient & & Estuarine and continental shelf \\
\hline 2 & Fluvitrygon kittipongi & Endangered & & Freshwater \\
\hline 3 & Fluvitrygon oxyrhyncha & Endangered & Protected & Freshwater \\
\hline 4 & Fluvitrygon signifier & Endangered & Protected & Freshwater \\
\hline 5 & Fluvitrygon sp 'musi' 1 & - & & Freshwater \\
\hline 6 & Fluvitrygon sp 'musi' 2 & - & & Freshwater \\
\hline 7 & Himantura undulata & Vulnerable & & Estuarine and continental shelf \\
\hline 8 & Himantura uarnak & Vulnerable & & Estuarine and continental shelf \\
\hline 9 & Maculabatis gerrardi & Vulnerable & & Freshwater and continental shelf \\
\hline 10 & Pateobatis fai & Vulnerable & & Estuarine and continental shelf \\
\hline 11 & Pateobatis uarnacoides & Vulnerable & & Estuarine and continental shelf \\
\hline 12 & Pastinachus ater & Least concern & & Freshwater and brackish \\
\hline 13 & Telatrygon biasa & Least concern & & Estuarine and continental shelf \\
\hline 14 & Urogymmus polylepis & Endangered & Protected & Estuarine and continental shelf \\
\hline
\end{tabular}

Stingrays in South Sumatran waters are recorded from of up to more $100 \mathrm{~km}$ inland to the coastal zone area (Figure 1). Eight genera of stingrays are recorded in South Sumatran 
waters: Brevitrygon, Fluvitrygon, Himantura, Maculabatis, Pateobatis, Pastinachus, Telatrygon and Urogymnus. Five species of Fluvitrygon are recorded (Fluvitrygon kittipongi, Fluvitrygon oxyrhyncha, Fluvitrygon signifer, Fluvitrygon sp 'musi' 1 and Fluvitrygon sp 'musi' 2), consisting largest genus of this family in the area.

The occurence of 14 species indicate that South Sumatran waters are important habitat for stingrays of family Dasyatidae. Following IUCN Red List status, the status of stingrays in South Sumatran status covering from Endangered, Vulnerable, Data Deficient, Least Concern and not evaluated [9]. Two unidentified of Fluvitrygon from Musi River, tentatively identified as Fluvitrygon sp 'musi' 1 and Fluvitrygon sp 'musi' 2, probably represent new undescribed species. Recently, four species of singrays are protected by Indonesian law under decree of the Ministry of Environment and Forestry Number P.20/MENLHK/SETJEN/KUM.1/6/2018 about protected species in Indonesia, and three of them recorded in South Sumatran waters (Fluvitrygon oxyrhyncha, Fluvitrygon signifer and Urogymnus polylepis) (Table 1).

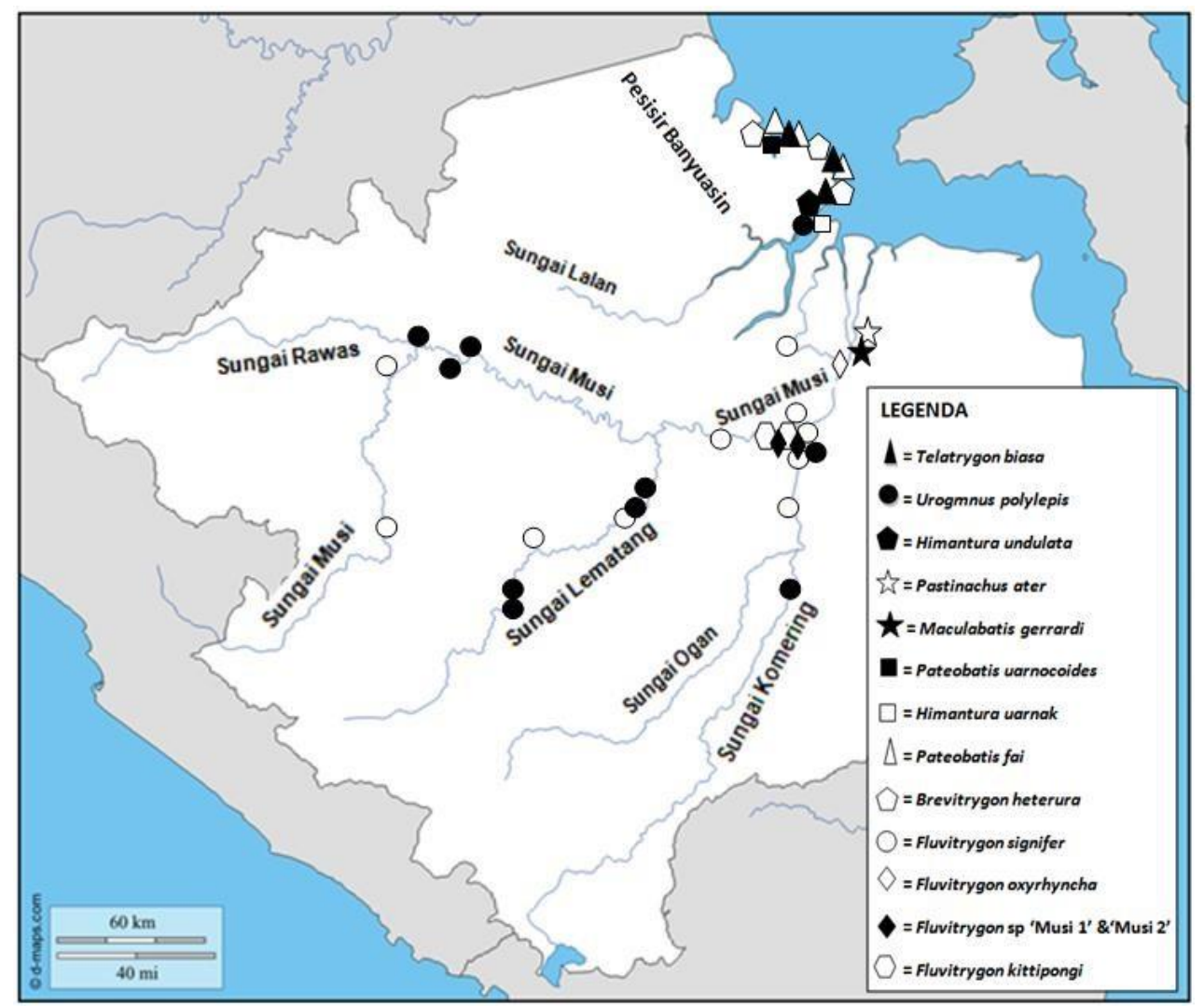

Fig. 1. Map of distributional records of stingrays found in South Sumatran waters 


\subsection{Reccomendation for Conservation Action Plan}

Conservation action plan is a powerful guide conservation to develop focused strategies and measures of success. Proposed conservation action plan for each species of stingrays recorded in South Sumatran waters are proposed in table 2. This reccomendation adopt and modify conservation actions plan of stingrays proposed by [9].

In the case of other parts of many countries, many stingray species in South Sumatran waters also face high level of direct explotation, mainly for their skin or low-value meat. As reported by [2], there is considerable number of threatened stingrays in South-East Asia where catches are very high but declining, with fishers having to travel much further from port to maintain catches. Net and trawl fisheries in Indonesia and elsewhewe are very extensive and, as a result, many shallow-water ray species are heavily exploitated. The general lack of management measures based on scientific research and stock assesment is hindering the sustainable utilisation of these resources. Furthermore, the extensive loss and degradation of habitat such as coastal mangroves and embayments are other key threats to these coastal and inshore species.

Table 2. Proposed conservation action plan for management of stingrays in South Sumatran waters, Indonesia.

\begin{tabular}{|c|c|c|c|}
\hline No & Species & Conservation Actions & Source \\
\hline 1 & Brevitrygon heterura & $\begin{array}{c}\text { Further research is required on data } \\
\text { abundanceand/or distribution, as well as } \\
\text { assessing the interactions of the species with } \\
\text { commercial fisheries, which will allow a } \\
\text { more accurate monitoring of population } \\
\text { trends }\end{array}$ & White et al., 2016a \\
\hline 2 & Fluvitrygon kittipongi & $\begin{array}{l}\text { Monitoring of quality of its habitat and } \\
\text { thenumber of mature individuals is inferred } \\
\text { as a result of habitat destruction and } \\
\text { pollution, and bycatch in freshwater fisheries }\end{array}$ & $\begin{array}{l}\text { Vidthayanon, \& } \\
\text { Manjaji- } \\
\text { Matsumoto, } 2016\end{array}$ \\
\hline 3 & $\begin{array}{l}\text { Fluvitrygon } \\
\text { oxyrhyncha }\end{array}$ & $\begin{array}{l}\text { Monitoring of intensive threat from } \\
\text { fisheries,pollution, logging in the catchment } \\
\text { areas and river engineering projects and is a } \\
\text { desirable aquarium species }\end{array}$ & Compagno, 2016a \\
\hline 4 & Fluvitrygon signifier & $\begin{array}{l}\text { Monitoring of freshwater habitats that are } \\
\text { underintensive threat from fisheries, } \\
\text { pollution, logging in the catchment areas and } \\
\text { river engineering projects }\end{array}$ & Compagno, 2016a \\
\hline 5 & Fluvitrygon sp 'musi' 1 & $\begin{array}{l}\text { Specimen collection and examination of the } \\
\text { studyskin and DNA are needed for } \\
\text { confimation of the proper identification as } \\
\text { well as to ensure taxonomic status }\end{array}$ & Our reccomendation \\
\hline 6 & Fluvitrygon sp 'musi' 2 & $\begin{array}{l}\text { Specimen collection and examination of the } \\
\text { studyskin and DNA are needed for } \\
\text { confimation of the proper identification as } \\
\text { well as to ensure taxonomic status }\end{array}$ & Our reccomendation \\
\hline 7 & Himantura undulata & $\begin{array}{l}\text { Research is required to assess catches of } \\
\text { Bleeker's Variegated Whipray throughout its } \\
\text { range, and to examine its habitat, ecology and } \\
\text { life history parameters including confirmation } \\
\text { of its distributional range. The fisheries that }\end{array}$ & Rigby, 2012 \\
\hline
\end{tabular}




\begin{tabular}{|c|c|c|c|}
\hline & & $\begin{array}{l}\text { capture this species are largely unregulated } \\
\text { (licenses are issued but catches and landings } \\
\text { are not properly monitored), and presently } \\
\text { there are no specific conservation actions in } \\
\text { place to help address this problem }\end{array}$ & \\
\hline 8 & Himantura uarnak & $\begin{array}{l}\text { Further research is required on the } \\
\text { speciebiology, as is assessment of catches } \\
\text { throughout its range }\end{array}$ & $\begin{array}{l}\text { Manjanji- } \\
\text { Matsumoto et al., } \\
2016 \mathrm{c} \\
\end{array}$ \\
\hline 9 & Maculabatis gerrardi & $\begin{array}{l}\text { Monitoring surveys should to ascertain the } \\
\text { statusand possible threats to this species here, } \\
\text { as well as in other portions of its range (New } \\
\text { Guinea and Indonesia), efforts in further } \\
\text { research should be directed to also obtain the } \\
\text { population, habitat and ecology and life } \\
\text { history parameters }\end{array}$ & $\begin{array}{l}\text { Manjanji- } \\
\text { Matsumoto et al., } \\
2016 \mathrm{c}\end{array}$ \\
\hline 10 & Pateobatis fai & $\begin{array}{l}\text { Further research is required to defined its } \\
\text { rangethroughout the Indo-West Pacific where } \\
\text { It is frequently misidentified as } P \text {. jenkinsii, } \\
\text { which can complicate species-specific catch } \\
\text { data, and monitoring high levels of } \\
\text { exploitation throughout its range in Southeast } \\
\text { Asia where the species is commonly caught } \\
\text { in multiple types of fisheries }\end{array}$ & $\begin{array}{l}\text { Manjanji- } \\
\text { Matsumoto et al., } \\
2016 \mathrm{c}\end{array}$ \\
\hline 11 & Pateobatis uarnacoides & $\begin{array}{l}\text { Further survey regarding specific information } \\
\text { oncatches in other parts of the species' range, } \\
\text { monitoring population declines elsewhere } \\
\text { from Indonesia, and monitoring coastal } \\
\text { degradation that impacted to this species }\end{array}$ & White et al., 2016a \\
\hline 12 & Pastinachus ater & $\begin{array}{l}\text { Further research is required on the species' } \\
\text { life-history', as well as assessing the } \\
\text { interactions of the species with commercial } \\
\text { fisheries, which will allow a more accurate } \\
\text { monitoring of population trends }\end{array}$ & Morgan et al., 2016 \\
\hline 13 & Telatrygon biasa & $\begin{array}{l}\text { Further research is required on the species' } \\
\text { life-history', as well as assessing the } \\
\text { interactions of the species with commercial } \\
\text { fisheries, which will allow a more accurate } \\
\text { monitoring of population trends }\end{array}$ & Our reccomendation \\
\hline 14 & Urogymnus polylepis & $\begin{array}{c}\text { Further research and survey are required to } \\
\text { confirm the presence, population trend, and } \\
\text { taxonomic status of populations of the species } \\
\text { from all parts of its range, especially India, } \\
\text { Bangladesh, Myanmar, Viet Nam, parts of } \\
\text { Indonesia and Malaysia, and Papua New } \\
\text { Guinea }\end{array}$ & $\begin{array}{l}\text { Vidthayanon, et al., } \\
2016\end{array}$ \\
\hline
\end{tabular}

\section{Conclusion}

When regional priorities have been set, conservation action planning is used to determine the plan of action for these priorities. The conservation action plans above would have not been possible without information on basic data information of each stingrays species. Providing basic data of stingrays diversity and distribution in South Sumatra 
demontrate the role of science in management of rare, globally threatened and protected aquatic biodiversity. As actions are taken and outcomes are measured, conservation action plans are revised to incorporate new knowledge. It is hope that the proposed conservation action above will beguideline for stake holders authority in the development of conservation of rare and protected aquatic species in South Sumatran waters.

\section{Acknowledgments}

We are very grateful to Department of Biology of Faculty of Math and Mathematic Science of Universitas Sriwijaya. Thank to Dr. Arum Setiawan, Dr. Laila Hanum Dr. Yuanita Windusari and Doni Setiawan for facilitating us conducting field surveys in Musi River and east coast of Banyuasin. We thank friends from Mancing Mania Palembang facebook groups who share their datas and allowing us use their photos, particularly Amran Halim and Febri Ansyah).

\section{References}

1. Compagno, L. J. V. \& Roberts, T. R. Environmental Biology of Fishes 7, 4 (1982

2. Last, P. R., Naylor, G. J. P., \&Manjaji-Matsumoto, B. M., Zootaxa 4139 (2016a)

3. Kottelat, M., The fishes of the inland waters of Southeast Asia: a catalogue and core bibliography of the fishes known to occur in freshwaters, mangroves, and estuaries (2013)

4. Husnah., Nurhayati, E., \&Suryati, N. K., Diversity, morphological characters and habitat of fish in Musi River drainage area, South Sumatra. (Research Institute for Inland Fisheries, Mariana, 2008)

5. Iqbal, M, Setiawan, D., \& Ajiman. Ichthyological Exploration of Freshwater 28, 1 (2017)

6. Iqbal, M., Setiawan, D., \& Ajiman. Ichthyological Exploration of Freshwaters 28, 2 (2018a)

7. Iqbal, M. \&Yustian, I., Exploration of Freshwaters 27, 4 (2016)

8. Iqbal, M. \&Yustian, I. Ichthyological Exploration of Freshwater 27, 4 (2016)

9. IUCN. 2018. The IUCN Red List of Threatened Species, (2018) 